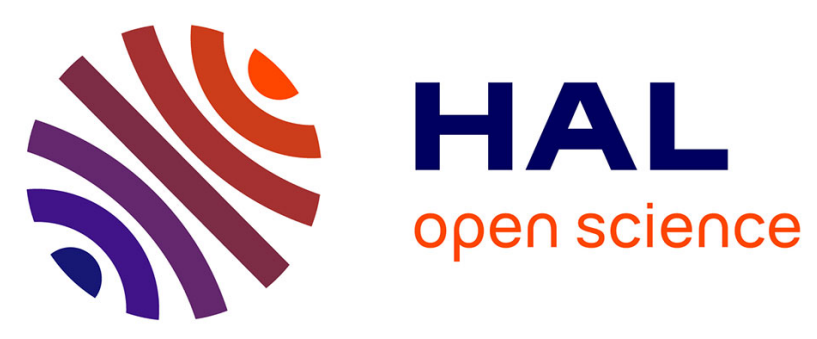

\title{
Carbon isotope evidence for sedimentary miliacin as a tracer of Panicum miliaceum (broomcorn millet) in the sediments of Lake le Bourget (French Alps).
}

Jérémy Jacob, Jean-Robert Disnar, Gérard Bardoux

\section{- To cite this version:}

Jérémy Jacob, Jean-Robert Disnar, Gérard Bardoux. Carbon isotope evidence for sedimentary miliacin as a tracer of Panicum miliaceum (broomcorn millet) in the sediments of Lake le Bourget (French Alps).. Organic Geochemistry, 2008, 39 (8), pp.1077-1080. 10.1016/j.orggeochem.2008.04.003 . insu00272141

HAL Id: insu-00272141

https://hal-insu.archives-ouvertes.fr/insu-00272141

Submitted on 11 Apr 2008

HAL is a multi-disciplinary open access archive for the deposit and dissemination of scientific research documents, whether they are published or not. The documents may come from teaching and research institutions in France or abroad, or from public or private research centers.
L'archive ouverte pluridisciplinaire HAL, est destinée au dépôt et à la diffusion de documents scientifiques de niveau recherche, publiés ou non, émanant des établissements d'enseignement et de recherche français ou étrangers, des laboratoires publics ou privés. 


\title{
Carbon isotope evidence for sedimentary miliacin as a tracer of Panicum miliaceum (broomcorn millet) in the sediments of Lake le Bourget (French Alps).
}

\author{
Jérémy Jacob $^{1 *}$, Jean-Robert Disnar ${ }^{1}$, Gérard Bardoux ${ }^{2}$.
}

1. ISTO, UMR 6113 du CNRS/Université d'Orléans, Bâtiment Géosciences, 45067 Orléans, France.

2. BIOEMCO, UMR 7618 du CNRS/INRA Centre de Versailles-Grignon, Bâtiment EGER, FR-78850 Thiverval-Grignon, France.

\begin{abstract}
We here report on the determination of the carbon isotopic composition of miliacin (olean-18-en-3ßol methyl ether), extracted from the sediments of Lake le Bourget (French Alps). It is compared to the $\delta^{13} \mathrm{C}$ of miliacin extracted from Panicum miliaceum (broomcorn millet, a C4 plant) and Chionochloa sp. (a C3 plant). The $\delta^{13} \mathrm{C}$ of sedimentary miliacin (-21.5 $\%$ ) is very close to that of miliacin extracted from bran (-23\%o) and seeds $(-23.5 \%)$ of $P$. miliaceum and significantly different from that of Chionochloa sp. $(-33 \%)$. These results provide additional support for the use of sedimentary miliacin as a tracer of broomcorn millet, a C4 cereal cultivated since the Bronze Age around Lake le Bourget. These findings illustrate the potential of this compound to reconstruct past agriculture from lake sediment archives. Finally, considering the high abundances of miliacin in the bran of $P$. miliaceum this compound could have been wind-transported to the sediment during threshing and winnowing on the lake shore.
\end{abstract}

\footnotetext{
* Corresponding author e-mail address : jeremy.jacob@univ-orleans.fr (J. Jacob)
} 


\section{Introduction}

The development of novel tracers permitting unravelling possible interactions between past climate and human activities is of direct relevance within the context of future Global Change (Dearing, 2006). We recently proposed that miliacin (olean-18-en-3 $\beta$-ol methyl ether or germanicol methyl ether, Figure 1) detected in the sediments of Lake le Bourget (French Alps) could be a specific tracer for the former cultivation of Panicum miliaceum (broomcorn millet) in the catchment (Jacob et al., 2008). This assumption was based on the fact that miliacin is the sole pentacyclic triterpene methyl ether (PTME) found in Lake le Bourget sediments. Because of the peculiar resistance of PTMEs to diagenesis (Jacob et al., 2005), this implies that miliacin was certainly the sole PTME produced in large amounts in the catchment. Few plants are reputed to synthesize miliacin as the sole PTME. These consist of Microstegium vimineum, Syntherisma sanguinalis, Glyceria acutiflora, Panicum sp. and P. miliaceum (Jacob et al., 2005). By comparing this list with an archaeobotanical inventory of plants that developed around the lake during the Bronze Age (Bouby and Billaud, 2001), we conclude that $P$. miliaceum is the most probable biological source of miliacin in the sediments. Therefore, miliacin in the sediments of Lake Le Bourget attest to the large development of $P$. miliaceum in the catchment. Since this plant is not indigenous to the study area, this implies that this plant was intentionally introduced (for agriculture) and that sedimentary miliacin attests to the cultivation of $P$. miliaceum in the watershed. As a matter of fact, the first appearance of miliacin in the sediments around $1700 \mathrm{BC}$ slightly precedes the expected introduction of $P$. miliaceum in the region (Marinval, 1995). In addition, the drastic decrease of miliacin concentrations around 800 BC coincides with several evidences of human abandonment of lake shore dwellings due to a phase of climatic deterioration (Magny, 2004; Billaud and Marguet, 2005). 
Despite these arguments, the certification of $P$. miliaceum as the source of miliacin in the sediments of Lake le Bourget requires additional investigation. P. miliaceum is a $\mathrm{C} 4$ plant imported from Asia whereas plants growing naturally around in the Alps have a C3 metabolism. By comparing the $\delta^{13} \mathrm{C}$ of miliacin extracted form these sediments with that of miliacin extracted from P. miliaceum and Chionochloa sp., we aim to confirm the use of sedimentary miliacin as a tracer of $P$. miliaceum, and by extension, of human cropping.

\section{Samples and Methods}

\subsection{Isolation of miliacin}

Sediment extraction was described previously (Jacob et al., 2008). The resultant neutral lipid fractions of eleven $1 \mathrm{~cm}$-thick sediment samples (22 $\mathrm{g}$ in total) from Lake le Bourget core LDB04 (at depths corresponding to the 1225 - 770 BC time interval; Jacob et al., 2008) were combined in order to obtain enough miliacin for $\delta^{13} \mathrm{C}$ measurements. This extract was dissolved in $0.5 \mathrm{ml}$ of hexane and then fractionated by flash chromatography on silica first activated at $110{ }^{\circ} \mathrm{C}$ for $48 \mathrm{~h}$ and then deactivated with $5 \%$ water. After the successive elution of aliphatic hydrocarbons (fraction F1 obtained with $2 \mathrm{ml}$ hexane) and aromatics (fraction F2 obtained with $1 \mathrm{ml}$ hexane and $2 \mathrm{ml}$ hexane:toluene 3:1), miliacin was found in fractions F3 and F4 obtained with $2 \mathrm{ml}$ hexane:toluene ( 1:1) and $2 \mathrm{ml}$ hexane:ethyl acetate (19:1,), respectively. Fractions F3 and F4 were combined and dried under nitrogen.

$4.3 \mathrm{~g}$ of $P$. miliaceum seeds and $2.4 \mathrm{~g}$ of $P$. miliaceum bran were extracted with the same protocol as described in Jacob et al. (2008). The total extracts were dissolved in $2 \mathrm{ml}$ of hexane, and $0.5 \mathrm{ml}$ of each extract was fractionated as above. Purified miliacin was obtained from Pr. R. Smith (Loughborough University, UK) and Pr. H.E. Connor (Christchurch University, NZ). This compound was purified from Chionochloa sp. extracts (Russell et al., 1976; Connor and Purdie, 1976; Connor, 2004). 


\subsection{GC-MS analyses}

In order to verify the purity of miliacin in the combined F3+F4 fraction of $P$. miliaceum seeds and bran as well as in F3+F4 fraction of LDB04 sediment extracts, these fractions were analysed by GC-MS on a TRACE-PolarisGCQ. The gas chromatograph was fitted with a Rtx-5MS capillary column (30 m, $0.25 \mathrm{~mm}$ i.d., $0.25 \mu \mathrm{m}$ film thickness) with 5 $\mathrm{m}$ of guard column. The GC operating conditions were: temperature held at $40{ }^{\circ} \mathrm{C}$ for $1 \mathrm{~min}$, then increased from 40 to $120{ }^{\circ} \mathrm{C}$ at $30{ }^{\circ} \mathrm{C} \min ^{-1}, 120$ to $300{ }^{\circ} \mathrm{C}$ at $3{ }^{\circ} \mathrm{C} \mathrm{min}{ }^{-1}$, with a final isothermal hold at $300{ }^{\circ} \mathrm{C}$ over $30 \mathrm{~min}$. The sample was injected splitless, with the injector temperature set at $280{ }^{\circ} \mathrm{C}$. Helium was the carrier gas. The mass spectrometer was operated in the electron ionisation (EI) mode at $70 \mathrm{eV}$ ionization energy and scanned from 50 to $600 \mathrm{Da}$. Concentrations of miliacin were estimated by using pure miliacin isolated from Chionochloa sp. as external standard.

\subsection{GC-C-IRMS analyses}

Miliacin standard, miliacin extracted from $P$. miliaceum bran and the miliacincontaining fraction from Lake le Bourget sediments were analysed by GC-C-IRMS, in a continuous flow mode. $\delta^{13} \mathrm{C}$ values were determined with a HP5860 gas chromatograph coupled to a Micromass Optima (GVI) isotope ratio mass spectrometer via an Isochron III combustion interface heated at $850{ }^{\circ} \mathrm{C}$. The gas chromatograph was fitted with a BPX 5 column (60m, $0.32 \mathrm{~mm}$ i.d., $0.25 \mu \mathrm{m}$ film thickness). The GC operating conditions were: temperature held at $50{ }^{\circ} \mathrm{C}$ for $2 \mathrm{~min}$, then increased from 40 to $200^{\circ} \mathrm{C}$ at $30{ }^{\circ} \mathrm{C} \mathrm{min}^{-1}, 120$ to $350{ }^{\circ} \mathrm{C}$ at $5{ }^{\circ} \mathrm{C} \mathrm{min}^{-1}$, with final isothermal hold at $350{ }^{\circ} \mathrm{C}$ over $20 \mathrm{~min}$. The samples were injected in splitless mode, with the injector temperature set at $280{ }^{\circ} \mathrm{C}$. Helium was the carrier gas. Ultra high purity carbon dioxide gas with known $\delta^{13} \mathrm{C}$ value was pulsed three times at the 
beginning and end of each analysis. The accuracy of carbon isotope measurements was evaluated using a standard of three n-alkanes and dodecanoic methyl ester with offline measured $\delta^{13} \mathrm{C}$ values (VGmix from Micromass). All $\delta^{13} \mathrm{C}$ values are reported in standard \%o notation relative to VPDB.

\subsection{TC/EA-IRMS analyses}

Standard miliacin crystals purified from Chinochloa sp. extracts were analysed by Thermal Conversion/Elemental Analyzer-Isotope Ratio Mass Spectrometry (TC/EA-IRMS) in dual inlet mode. $\delta^{13} \mathrm{C}$ values were determined with a CARLO ERBA NA 1500 elemental analyser coupled to a Micromass SIRA 10, via a triple trap purification interface.

\section{Results and discussion}

Partial Total Ion Chromatograms (TIC) of the F3+F4 fraction obtained from Lake le Bourget sediments, P. miliaceum seeds and bran extracts and pure miliacin extracted from Chionochloa sp. are displayed in Figure 2. All TIC traces show relatively pure miliacin that elutes at $40.75 \mathrm{~min}$ in our temperature programme. The absence of any other fragment than those typical for miliacin mass spectra in the peaks eluting at 40.75 min with our temperature programme allowed us to exclude any significant coelution in all analyses (Figure 3). Concentrations in miliacin of the different samples are reported in Table 1. P. miliaceum seeds and bran contain 0.3 and $0.16 \mathrm{mg} \cdot \mathrm{g}^{-1}$ (plant dry mass) of miliacin, respectively. The average concentration of miliacin in the selected samples from Lake le Bourget sediments reaches $0.49 \mu \mathrm{g} \cdot \mathrm{g}^{-1}$ sediment.

The first record of miliacin in the literature was provided by Itô (1934) in a paper dealing with the chemical composition of some gramineae oils. This author found miliacin in 
P. miliaceum and Syntherisma sanguinalis (hairy crabgrass). Miliacin was also found in several species of Chionochloa, sometimes associated with other PTMEs such as arundoin, lupeol methyl ether, $\beta$-amyrin methyl ether, parkeol and cycloartenol methyl ethers (Russell et al., 1976; Connor and Purdie, 1976; Connor, 2004). Miliacin is the sole PTME detected in Glyceria acutiflora. It also occurs in Eragrostis ferruginea where it is associated with $\beta$ amyrin methyl ether (see Ohmoto et al., 1970). As a conclusion, miliacin is found principally in gramineae with either a $\mathrm{C} 3$ or $\mathrm{C} 4$ metabolism.

Offline and online measurements of purified miliacin extracted from Chionochloa $s p$. are in rather good agreement (-31.2 and $-33 \%$, respectively) and are consistent with a C3 metabolism. The difference between these two values might arise from a compound present in low amounts in the "purified" extract.

Miliacin extracted from $P$. miliaceum seeds and bran have $\delta^{13} \mathrm{C}$ values of $-23.5 \%$ and $-23 \%$, respectively, i.e. typical for a lipid derived from $\mathrm{C} 4$ plants. The $\delta^{13} \mathrm{C}$ of miliacin extracted from Lake le Bourget sediments $(-21.5 \%$ ) is close to that of miliacin extracted from P. miliaceum, as opposed to the $\delta^{13} \mathrm{C}$ of miliacin extracted from Chionochloa sp. (-33\%o). This indicates that miliacin detected in the Lake le Bourget sediments was produced by a $\mathrm{C} 4$ plant. Since most of plants growing naturally in the Alps are C3 plants, miliacin extracted from Lake le Bourget sediments was probably produced by a $\mathrm{C} 4$ producer plant foreign to the study area, such as P. miliaceum. This is a further support for miliacin as a tracer specifically for P. miliaceum around Lake le Bourget.

These results not only provide further evidence on the origin of sedimentary miliacin but also allow the formulation of new assumptions on the transportation of this molecule from the plant to the sediment. We previously assumed that miliacin is present in plant epicuticular waxes (Jacob et al., 2008), as is the case for other pentacyclic triterpenes. High concentrations 
of miliacin in $P$. miliaceum bran suggest that this part of the plant could also be an important contributor of sedimentary miliacin, for example by wind transport during winnowing.

\section{Conclusion}

The carbon isotopic composition of miliacin detected in the sediments of Lake le Bourget provides further evidence that $P$. miliaceum, a $\mathrm{C} 4$ plant, was the biological source of this molecule in this context. This result strengthens the confidence with which miliacin can be used to unravel the history of millet cultivation in sedimentary archives. In addition, the unique source of miliacin makes this biomarker a suitable target to unravel the evolution of environmental parameters from its carbon and hydrogen isotopic compositions. In a larger way, these findings also illustrate the possibilities of the molecular biomarker approach to better understand past interactions between climate, environment and human societies.

\section{Acknowledgments}

This work is part of the APHRODYTE project, supported by the French CNRS (Programme ECLIPSE 2005-2006). E. Gaillard from HITEX is kindly acknowledged for providing bran and seeds of $P$. miliaceum. Nicolas Péchot is acknowledged for performing EA-IRMS measurements. The authors wish to thank Pr. H.E. Connor (Christchurch University, New Zealand) and Pr. R. Smith (Loughborough University, United Kingdom) for providing purified miliacin.

\section{References}

Billaud, Y., Marguet, A., 2005. Habitats lacustres du Néolithique et de l'âge du Bronze dans les lacs alpins français. In: Della Casa Ph. and Trachsel M. (Eds.). WES'04, Wetland 
Economies and Societies. Proceedings of the International Conference in Zurich, 10-13 March 2004. Collectio Archaeologica 3, pp. 143-168 (Chronos, Zürich).

Bouby, L., Billaud, Y., 2001. Economie agraire à la fin de l'âge du Bronze sur les bords du Lac du Bourget (Savoie, France). Cr. Acad. Sci. II A 333, 749-756.

Bryce, T.A., Eglinton, G., Hamilton, R.J., Martin-Smith, M., Subramanian, G., 1967a. Triterpenoids from New Zealand plants - The triterpene methyl ethers of Cortaderia toetoe zotov. Phytochem. 6, 727-733.

Connor, H.E., 2004. Flora of New Zealand - Gramineae. Supplement I: Danthonioideae. New Zealand Journal of Botany 42, 771-775.

Connor, H.E., Purdie, A.W., 1976. Triterpene methyl ether differentiation in Chionochloa (Gramineae). New Zealand Journal of Botany 14, 315-326.

Dearing, J., 2006. Climate-human-environment interactions: resolving our past. Clim. Past 2, 187-203.

Itô, H., 1934. The chemical investigation of some gramineae oils. Jour. Fac. Agr. Hokkaido Imp. Univ. XXXVII, 1-40.

Jacob, J., Disnar, J.R., Boussafir, M., Sifeddine, A., Albuquerque, A.L.S., Turcq, B., 2005. Pentacyclic triterpene methyl ethers in recent lacustrine sediments (Lagoa do Caçó, Brazil). Org. Geochem. 36, 449-461.

Jacob, J., Disnar, J.R., Arnaud, F., Chapron, E., Debret, M., Lallier-Vergès, E., Desmet, M., Revel-Rolland, M. 2008. Millet cultivation history in the French Alps as evidenced by a sedimentary molecule. Journal of Archaeological Science 35, 814-820.

Magny, M., 2004. Holocene climate variability as reflected by mid-European lake-level fluctuations and its probable impact on prehistoric settlements. Quat. Int. 113, 65-79. 
Marinval, P., 1995. Données carpologiques françaises sur les Millets (Panicum miliaceum L. et Setaria italica L. Beauv.) de la Protohistoire au Moyen Age. In: Hörandner, E. (Ed.) Millet. Actes du Congrès d'Aizenay (1990). Peter Lang, Frankfurt, p. 31-61.

Ohmoto, T., Ikuse, M., Natori, S., 1970. Triterpenoids of the Gramineae. Phytochem. 6, $2137-$ 2148

Russell, G.B., Connor, H.E., Purdie, A.W., 1976. Triterpene methyl ethers of Chinochloa (Gramineae). Phytochem. 15, 1933-1935. 


\section{Table captions}

Table 1: Concentrations and $\delta^{13} \mathrm{C}$ values of miliacin extracted from $P$. miliaceum seeds and bran, Chionochloa sp. and the sediments of Lake le Bourget. Uncertainties are standard errors of the mean for 2 or 3 measurements. Where no uncertainty is given, values represent a single measurement.

\begin{tabular}{|c|c|c|c|c|}
\hline \multirow{2}{*}{ Sample } & \multirow{2}{*}{ Weight extracted } & \multirow{2}{*}{ Miliacin concentration } & \multicolumn{2}{|c|}{ Miliacin $\delta^{13} \mathrm{C}$ (\% VPDB) } \\
\hline & & & EA-IRMS & GC-IRMS \\
\hline P. miliaceum seeds & $4.3 \mathrm{~g}$ & $0.3 \mathrm{mg} / \mathrm{g}$ & & $-23.5 \pm 0.3$ \\
\hline P. miliaceum bran & $2.4 \mathrm{~g}$ & $0.16 \mathrm{mg} / \mathrm{g}$ & & $-23.0 \pm 0.3$ \\
\hline LDB04 sediment samples & $22 \mathrm{~g}$ & $0.49 \mu \mathrm{g} / \mathrm{g}$ & & $-21.5 \pm 0.3$ \\
\hline Chionochloa sp. & \multicolumn{2}{|c|}{ Purified compound } & -31.2 & $-33.0 \pm 0.3$ \\
\hline
\end{tabular}

\section{Figure captions}

Figure 1: Structure of miliacin (olean-18-en-3ßol methyl ether or germanicol methyl ether).

Figure 2: Partial GC-MS TIC traces of: (i) Chionochloa sp. purified miliacin; (ii) F3+F4 fractions of lipid extract from Panicum miliaceum; (iii) F3+F4 fractions from Lake le Bourget sediments.

Figure 3: Mass spectra of (a) miliacin extracted from Lake le Bourget sediments, (b) miliacin extracted from P. miliaceum bran and (c) purified miliacin from Chionochloa sp. 
Figure 1

(1) 
Figure 2

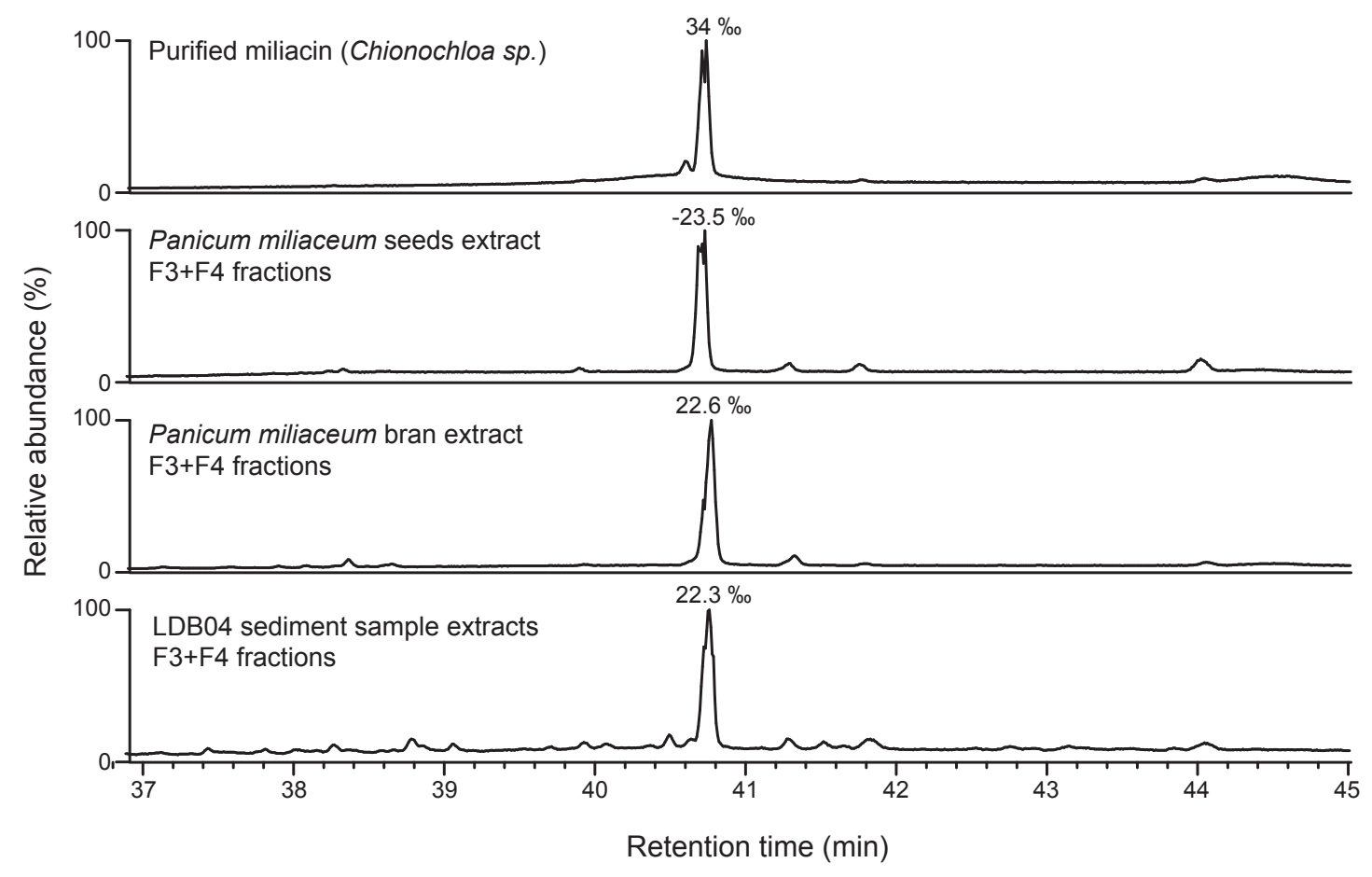


Figure 3

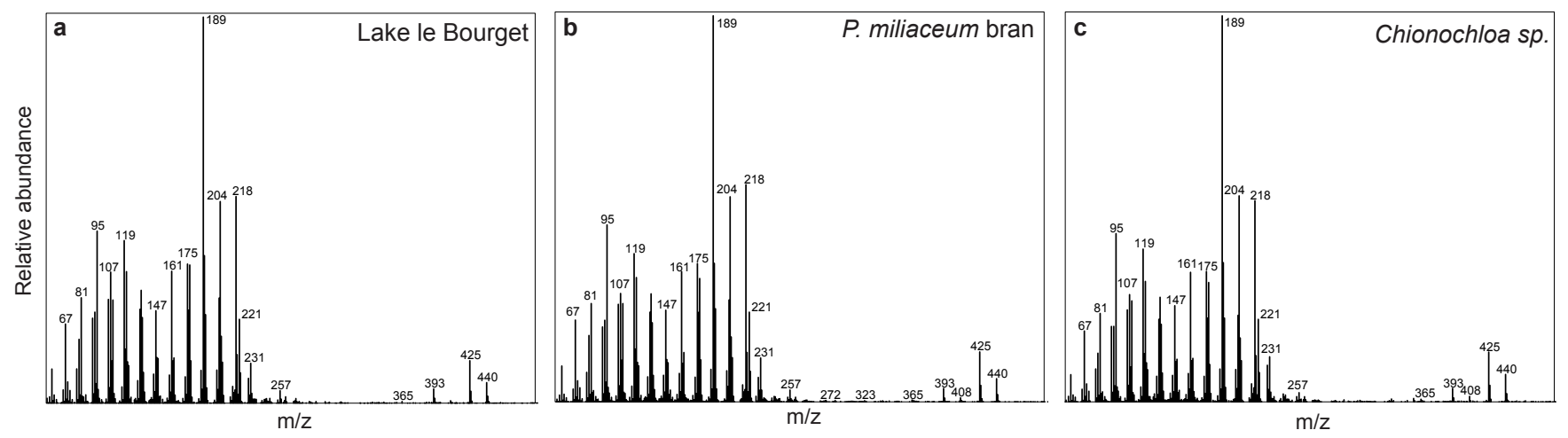

